Jurnal Mahasiswa BK An-Nur : Berbeda, Bermakna, Mulia

Volume 7 Nomor 3 Tahun 2021

Tersedia Online: https://ojs.uniska-bjm.ac.id/index.php/AN-NUR

p-ISSN. 2460-9722 | e-ISSN. 2622-8297

\title{
IDENTIFIKASI PUTUSAN KARIR MAHASISWA UNIVERSITAS TEKNOLOGI YOGYAKARTA MENGGUNAKAN APLIKASI ANDROID MIHG (MULTIPLE INTELLIGENCE BY HOWARD GARDNER)
}

\author{
Widi Fajar Widyatmoko ${ }^{1}$, Ari Prasetyoaji ${ }^{2}$ \\ ${ }^{1,2}$ Universitas Teknologi Yogyakarta \\ E-mail: widifajar@uty.ac.id / 0818260554 \\ ariprasetyoaji@uty.ac.id / 08176378910
}

\begin{abstract}
ABSTRAK
Pada jenjang pendidikan perguruan tinggi mahasiswa dikelompokkan di kelompok-kelompok bidang yang sesuai dengan pemilihan minanya. Individu memasuki jurusan tersebut untuk memperdalam ilmu pengetahuan dan kemampuan yang ada dalam dirinya. Berdasarkan fakta yang ditemukan di lapangan bahwa adanya kebutuhan mahasiswa terhadap pembimbingan karir yang akan dituju. Tantangan yang dihadapi mahasiswa dalam menentukan karir, di antaranya adalah ketidak pastian karir, pengaksesan informasi dan program pengembangan karir, dan tangangan-tantangan ekonomi dan teknologi, terutama dalam menghadapi revolusi indusri 4.0 dan era society 5.0. Temuan dilapangan mengungkapkan bahwa tidak sedikit mahasiswa memiliki tingkat putusan karir yang masih tergolong belum optimal dimana sebanyak 71\% mahasiswa masih memerlukan bantuan mengenai putusan karir. Adanya aplikasi identifikasi kecerdasan individu ini dapat membantu mahasiswa dalam pengambilan putusan karir, Hal tersebut ditunjukan dengan hasil uji penggunaan media dilapangan bahwa 89\% mahasiswa UTY mengalami peningkatan putusan karir setelah menggunakan aplikasi identifikasi Multipple intellegence Howard Gardner. Maka, aplikasi multiple intelligence dalam membantu membuat putusan karir dikatakan layak digunakan sebagai media dalam membantu mahasiswa membuat putusan karir mahasiswa UTY.
\end{abstract}

Kata Kunci: Putusan Karir, Aplikasi Android, Multiple Intelligence

\begin{abstract}
The future challenges of higher education students for determining their future career in the era of industrial revolution 4.0 and society 5.0, getting more complex. Student may facing career uncertainty, lack of access to information and career development programs, and economic and technological challenges. Previous research shown many student need for career guidance to be addressed for choosing their course study. Student at the University level are grouped into groups of fields according to their choice of interests. Research findings in the field reveal that not a few students have a career decision level that is still not optimal, whereas many as $71 \%$ of students still need help regarding career decisions. The existence of this individual intelligence identification application can help students in making career decisions. This is shown by the results of the media use test in the field that $89 \%$ of UTY students experienced an increase in career decisions after using Howard Gardner's Multiple intelligence identification application. Thus, the application of multiple intelligence in helping to make career decisions is said to be suitable as a medium to help students make career decisions for UTY students.
\end{abstract}

Keywords: Career Decision, Android Application, Multiple Intelligence

Dipublikasikan Oleh :

UPT Publikasi dan Pengelolaan Jurnal

Universitas Islam Kalimantan Muhammad Arsyad Al-Banjari Banjarmasin 


\section{Widi Fajar Widyatmoko ${ }^{1}$, Ari Prasetyoaji ${ }^{2}$ \\ Jurnal Mahasiswa BK An-Nur : Berbeda, Bermakna, Mulia \\ Volume 7 Nomor 3 Tahun 2021 \\ Tersedia Online: https://ojs.uniska-bjm.ac.id/index.php/AN-NUR}

p-ISSN. 2460-9722 | e-ISSN. 2622-8297

\section{PENDAHULUAN}

Untuk pengoptimalan arah karir yang lebih baik individu perlu meningkatakan akan adanya pemahaman diri yang lebih baik lagi, pemahaman atas kecerdasan yang ada pada dirinya secara lebih baik lagi. Salah satu lembaga formal yang outputnya menyiapkan individu yang siap memasuki dunia kerja adalah universitas. Peserta didik yang ada dalam tingkat ini disebut dengan mahasiswa. Pada tingkat akhir mahasiswa diharapkan telah mampu mandiri dan mampu mengambil keputusan sendiri terutama berkenaan dengan dirinya. Salah satu tugas perkembangan yang dilalui oleh mahasiswa dia khir pendidikannya yaitu mampu melakukan pengambilan keputusan dalam menentukan pilihan karirnya.

Pada dasaranya mahasiswa pada tingkat Perguruan Tinggi sudah dikelompokkan sesuai dengan jurusan-jurusan yang lebih spesifik lagi dalam suatu bidang tertentu. Individu memasuki jurusan tersebut guna untuk memperdalam ilmu pengetahuan dan kemampuan yang ada dalam dirinya, untuk emngejar karir yang akan dipilihnya setelah menyelesaikan pendidikan dijenjang perguruan tinggi. Namun tidak menutup kemungkinan bahwa seseorang akan memilih karir yang tidak sesuai dengan jruuan yang sedang ditempuhnya saat ini. Hal ini dapat dipengaruhi oleh beberapa faktor seperti keluarga, lingkungan, dan sebagainya ( Ebtanastiti \& Muis, 2014). Seginer ( Dewi, 2020) menyatakan bahwa pengambilan keputusan karir menjadi sangat penting karena menentukan berhasill atau tidak mahasiswa di masa depan. Berbagai penelitian yang telah terjadi selalu konsisten menunjukan bahwa para peserta didik yang telah membuat pilihan karir masa depan memiliki kualitas hidup yang lebih baik daripada yang belum memutuskan. Fakta dilapangan menunjukan bahwa tidak semua mahasiswa semester akhir dapat melakuka pengambilan keputusan karirnya.

Berdasarkan fakta yang ditemukan di lapangan bahwa adanya kebutuhan mahasiswa terhadap pembimbingan terhadap karir yang akan dituju. Tantangan yang akan dihadapi mahasiswa dalam menentukan karir, di antaranya adalah ketidak pastian karir, pengaksesan informasi dan program pengembangan karir, dan tangangan-tantangan ekonomi dan teknologi, terutama dalam menghadapi revolusi indusri 4.0 dan era society 5.0. Untuk mengantisipasi tantangan-tantangan ini perlu bagi perguruan tinggi untuk memberikan pelayanan yang optimal terhadap perkembangan karir mahasiswa.

Setiap diri manusia memiliki intelligence yang beragam, hanya saja untuk mengoptimalkannya setiap individu memerlukan pemahaman yang lebih mendalam serta memahami kearah mana intelligence yang dimilikinya. Sukmadinata mengungkapkan bahwa setiap individu memiliki kecerdasan yang berbeda, individu memiliki beberapa kecerdasan, dan kecerdasan-kecerdasan itu bergabung menjadi satu kesatuan dan membentuk kemampuan pribadi yang cukup tinggi, Gardner menyatakan bahwa seorang anak manusia lahir ke dunia memiliki lebih dari satu potensi kecerdasan yang mungkin bisa berkembang, walaupun perkembangan tersebut berbeda dari satu orang dengan orang lain. Kecerdasan berkembang sesuai dengan lingkungan yang berpengaruh pada seorang diri individu [1]. Maka itu kecerdasanlah yang menjadikan perbedaan antara seorang dengan yang lainnya [8]. Kecerdasan menurut paradigma multiple intelligence Gardner [1] didefinisikan sebagai kemampuan yang mempunyai tiga komponen utama yaitu, kemampuan untuk menyelesaikan masalah yang terjadi dalam kehidupan nyata seharihari, kemampuan untuk menghasilkan persoalanpersoalan baru yang dihadapi untuk diselesaikan, dan kemampuan untuk menciptakan sesuatu atau menawarkan jasa yang akan menimbulkan penghargaan dalam budaya sesesorang.

Gardner menyusun daftar kecerdasan dalam buku "Frames of Mind yakni kecerdasan linguistic, kecerdasan logis-matematis, kecerdasan visualspasial, kecerdasan musical, kecerdasan gerak tubuh, kecerdasan interpersonal, kecerdasan intrapersonal, kecerdasan lingkungan, kecerdasan eksistensial. Teori multiple intelligence ini seolah menjawab kegelisahan pada dunia pendidikan yang dimana manusia hanya dipandangan kecerdasannya melalui dua jenis yaitu kecerdasan logika-matematika dan linguistic saja. Penerapan teori multiple intelligence menegaskan bahwa setiap individu yang hidup di bumi terlahir dengan sejumlah kecerdasan potensial dan diberkahi dengan keunikan unik untuk dikembangkan juga meningkatkan kemampuan dan mencapai tujuan dan sasaran kehidupan, terutama dalam proses pendidikan. Selain untuk menegaskan bahwa setiap individu memiliki keunikan tersendiri, multiple intelligence jika dipahai dapat membantu individu dalam menentukan arah karirnya, kecenderungan arah karirnya dapat dilihat lebih jelas ketika memahami ke arah mana kecerdaran diri sendiri.

Setiap individu yang sedang atau dalam masa kerjanya berhak untuk memiliki pengetahuan memahami multiple intelligence, hal tersebut berguna untuk mendukung pilihan karir kedepannya bagi para individu yang ingin mencari pekerjaan atau melanjutkan study, dan bagi individu yang sudah bekerja multiple intelligence dapat berguna untuk

Dipublikasikan Oleh :

UPT Publikasi dan Pengelolaan Jurnal

Universitas Islam Kalimantan Muhammad Arsyad Al-Banjari Banjarmasin 


\section{Widi Fajar Widyatmoko ${ }^{1}$, Ari Prasetyoaji ${ }^{2}$ \\ Jurnal Mahasiswa BK An-Nur : Berbeda, Bermakna, Mulia \\ Volume 7 Nomor 3 Tahun 2021 \\ Tersedia Online: https://ojs.uniska-bjm.ac.id/index.php/AN-NUR \\ p-ISSN. 2460-9722 | e-ISSN. 2622-8297}

membantu meningkatkan individual skill sehingga dapat membantu dalam kenaikan jenjang karirnya.

Sebuah hasil penelitian yang dilakukan menyatakan bahwa $80 \%$ prestasi kerja ditentukan oleh soft skill (Karakter) dan hanya 20\% hard skill (pengetahuan dan keterampilan). Sekolah merupakan institusi yang paling strategis dalam pengembangan karakter yang sejatinya tertuang dalam rencana strategis sekolah (renstra). Namun, realitas lembaga pendidikan di Indonesia dalam proses pembelajaran hanya memberikan porsi $10 \%$ soft skill sedangkan hard skill sebesar 90\% [4]. Berdasarkan riset data yang dilakukan oleh Hootsuite serta platform media we are social yang bertajuk global digital report 2020, menunjukan hasil bahwa 338.2 Million individu sebagai mobile phone connection, dan 175.4 Million dari total populasi 272.1 adalah pengguna internet. Hasil dari kuisioner tentang penilaian ketercapaian individu dalam membuat putusan karir pada mahasiswa UTY tahun 2021 didapatkan hasil bahwa $71 \%$ mahasiswa belum dapat mengambil keputusan karir dengan optimal. Mahasiswa UTY sebenarnya sudah mengambil mata kuliah pengembangan kepribadian dimana satu satu capaian pembelajarannya adalah bertambahnya pengetahui mengenai dirinnya dan arah kedepan dirinya akan menjadi seperti apa namun pada kenyataannya, masih banyak mahasiswa yang mengalami kebingungan dalam mengambil keputusan karir.

Menurut data dari BPS ( Badan Pusat Statisik) yang diril pada 05/05/2019 tingkat pengangguan terbuka di Indonesia mencapai 6,8 juta atau $5,01 \%$ dari angkatan kerja yang mencapai 136,2 juta. Tingkat penganggguran terbuka berdasarkan tingkat pendidikan pada tahun 2019. TPT untuk jenjang pendidikan SD ke bawah 2,65\%, SMP 5,04\%, SMA 6,78\%, SMK 8,63\% Diploma I-IV 6,89\%, dan Universitas 6,24\%. Jumlah TPT tertinggi berdasarkan jenjang pendidikan yaitu SMK (Sekolah Menengah Kejuruan) sebesar 8,63\% (BPS, 2019). Berdasarkan BPS di Yogyakarta terdapat Tingkat Pengangguran Terbuka (TPT) sebesar 2,86\% dari seluruh penduduk di wilayah Yogyakarta. Dari data tersebut dapat dirincikan menjadi $2,11 \%$ dari lulusan SD, $0,86 \%$ dari lulusan SMP, 3,99\% dari lulusan SMA, 3,76\% dari lulusan SMK, 6,78\% dari lulusan Diploma, dan 3,43 dari lulusan Universitas (BPS, 2019). Dari data tersebut dapat kita lihat bahwa tingkat pengangguran terbuka dari univiersitas sendiri mencapai angka $6,24 \%$ di Indonesia dan 3,43\% untuk wilayah Yogyakarta.

Sering terjadi permasalahan yang dihadapi para mahasiswa dan tidak dapat diatasi oleh dirinya sendiri sehingga membutuhkan bantuan dari pihak lain, di lingkungan perguruan tinggi yang berperan dalam membantu peserta didik dalam menangani permasalahan karir yaitu Konselor. Salah satu bidang dalam layanan bimbingan dan konseling yaitu bimbingan karir. (Winkel, 2010) mengungkapkan bahwa bimbingan karir adalah bimbingan dalam mempersiapkan diri menghadapi dunia kerja, dalam memilih lapangan kerja atau jabatan atau profesi tertentu serta membekali diri supaya siap memangku jabatan itu, dan dalam menyesuaikan diri dengan berbagai tuntutan dari lapangan pekerjaan yang dimasuki. Keterbatasan akses konselor di era seperti ini adalah keterbatasan tatap muka yang memungkinakan konselur melakukan asessment kepada konseli atas permasalahan yang dihadapinnya, diperlukan media yang dapat membantu konselor dalam mengidentifikasi diri konseli untuk dilakuka analisa lebih lanjut. Tidak ada bidang kehidupan yang tidak tersentuh oleh pengaruh dan perkembangan tenologi, maka kehadian media digital adalah solusi yang tepat di era teknologi ini. Hal tersebut sesuai dengan hasil survey awal yang mengungkapkan bahwa $73 \%$ peserta didik membutuhkan media digital yang mampu memberikan informasi mengenai multiple intelligence ( Howard Gardner).

\section{METODE}

Subjek penelitian ini adalah mahasiswa Universitas Teknologi Yogyakarta angkatan 2021. Pendekatan penelitian yang digunakan adalah pendekatan kuantitatif non-eksperimental. Untuk mengukur tingkat putusan karir digunakan angket yang mengandung aspek putusan karir, alat ukur ini terdiri dari 24 item yang merujuk pada dimensi putusan karir. Uji reliabilitas pada skala kematangan karir menunjukan koefisien sebesar 0,856 (Alpha Cronbach). Uji reliabilitas pada skala media menunjukan koefisien sebesar 0,811 ( Alpha Cronbach).

Metode analisis data yang digunakan pada penelitian ini adalah teknik statistik regresi linier sederhana. Analisis regresi linier sederhana digunakan untuk melihat bagaimana pengaru antara satu independent (IV) dengan satu dependent variabel (DV).

\section{HASIL DAN PEMBAHASAN}

Hasil dari observasi dan data kuisioner dilapangan menunjukan bahwa masih belum optimalnya kemampuan mahasiswa dalam membuat putusan karir, yang akhirnya menghambat perkembangan karir mahasiswa itu sendiri. Belum

Dipublikasikan Oleh : 


\section{Widi Fajar Widyatmoko ${ }^{1}$, Ari Prasetyoaji ${ }^{2}$ \\ Jurnal Mahasiswa BK An-Nur : Berbeda, Bermakna, Mulia \\ Volume 7 Nomor 3 Tahun 2021 \\ Tersedia Online: https://ojs.uniska-bjm.ac.id/index.php/AN-NUR \\ p-ISSN. 2460-9722 | e-ISSN. 2622-8297}

optimalnya pengambilan putusan karir individu itu sendiri salah satunya adalah kurangnya pemahaman mengenai macam-macam kecerdasaran yang dimiliki oleh individu, kecerdasan dalam dirinya dan kurangnya media yang dapat membantu individu dalam pengambilan putusan karir. Konselor dalam pelaksanaan layanan bimbingan karir mengalami keterbatasan akses disaat masa pandemic yang sedang terjadi kurangnya kemungkinan tatap muka dan tidak adanya akses media yang bisa membantu proses konseli menjadi hambatan konselor dalam membantu memahami kecerdasan yang ada dalam diri individu. Menurut hasil pengamatan dan survey lebih lanjut sudah ada media dalam layanan bimbingan karir sebelumnya namun media tersebut dalam penggunaannya belum bisa optimal dan juga belum secara spesifik membahas mengenai kecerdasan yang ada dalam diri individu. Hasil dari kuisioner yang telah disebarkan menggunaan media google form $71 \%$ mahasiswa belum memiliki tingkat keputusan karir yang belum optimal, selain aspek pembuatan keputusan karir yang tertera dalam kuisioner aspek lain yang ada didalamnya memuat tentang media sehingga didapatkan hasil bahwa $73 \%$ mahasiswa membutuhkan media digital yang dapat membantu dalam memahami kecerdasan yang ada dalam dirinya dan membantu membuat putusan karir, karena media digital dirasa lebih efektif dan efisien penggunaannya.

Hasil dari desain produk yang dirancang dengan mempertimbangkan beberapa aspek dimana karakteristik media adalah self instruction, self contained, self alone, adaptif, user friendly dan konsisten. Selian mempertimbangan aspek media, aplikasi ini juga mempertimbangan karakteristik multimeia interaktif yang memiliki kemudahan navigasi, kandungan kognisi yang jelas, presentasi yang digunakan, integrese media, dan gunsi secara keseluruhan. Pada bagian materi dikonstruk dari teori multiple intelligence yang dicetuskan oleh howard gardner yang terdiri atas 1) logical mathematical intelligence, 2) linguistic intelligence, 3) visualspasial intelligence, 4) bodily-kinesthetic intelligence, 5) musical intelligence, 6) interpersonal intelligence, 7) intrapersonal intelligence, 8) naturalist intelligence, dan 9) existensialis intelligence. Berdasarkan hasil dari penelitian penggunana media identifikasi multiple intellegence Howard Gardner mengungkapkan bahwa $89 \%$ mahasiswa UTY memiliki peningkatakan pemilihan putusan karir yang lebih optimal dari sebelumnya, hal tersebut didasarkan atas bantuan pemahaman menggunakan aplikasi identifikasi multiple intellegence sehingga mahasiswa lebih memahami mengenai kecerdasan yang ada pada dalam dirinya dan juga arah putusan karir kedepannya yang sesuai dengan kemampuan bakat minta dirinya sendiri.

\section{PENUTUP}

Pemahaman mahasiswa di UTY terhadap kecerdasan yang dimiliki dan kemampuan mengambil putusan karir masih tergolong rendah dan perlu dioptimalkan, $71 \%$ mahasiswa memiliki tingkat pengambilan putusan karir yang masih rendah, 73\% mahasiswa membutuhkan media yang dapat membantunya dalam pengambilan keputusan karir kedepannya sehingga karir dapat tercapai secara optimal. Hasil penelitian aplikasi multiple intelligence dalam membantu membuat putusan karir mahasiswa ini dapat digunakan oleh mahasiswa UTY. aplikasi ini mendapatkan respon yang baik, baik dari segi materi, bahasa, tampilan dan penggunaan. Hal tersebut ditunjukan dengan hasil uji penggunaan media dilapangan bahwa $89 \%$ mahasiswa UTY mengalami peningkatan putusan karir setelah menggunakan aplikasi identifikasi Multipple intellegence Howard Gardner. Maka, aplikasi multiple intelligence dalam membantu membuat putusan karir dikatakan layak digunakan sebagai media dalam membantu mahasiswa membuat putusan karir mahasiswa UTY.

\section{REFERENSI}

Ali, Noor Rochmad. 2015. Analisis Konsep Howard Gardner Tentang Kecerdasan Majemuk (Multiple Intelegence) dan Implikasinya Terhadap Pembelajaran yang Sesuai dengan Perkembangan Anak di TK Alam Alfa Kids Pati Tahun Ajaran 2014/2015. Universitas Negeri Walisongo: Semarang.

Efendi, Muhammad Arifin. 2019. Pengembangan Aplikasi Informasi Jenis Profesi Berbasis Android Untuk Layanan Informasi Karir Pada Peserta Didik Sekolah Menengah Atas Negeri 6 Bandar Lampung. Universitas Lampung.

Gardner, Howard. 2011. Frames of Mind "The Theory of Multiple Intelligences. New York: Basic Books.

Masaong, Kadim. 2012. Pendidikan Karakter Berbasis Multiple Intelligence. Konaspi VII Universitas Negeri Yogyakarta

Mundiri, A (2016) Strategi Lembaga Pendidikan Islam dalam Membangun Branding Image. Pedagogik, 3(2)

Mundiri, A., \& Zahra, I. 2017. Implementasi Metode Stifin dalam Meningkatkan Kemampuan Menghafal Al-Quran di Rumah Quran Stifin Paiton Probolinggo. Journal of Islamic Education

Dipublikasikan Oleh :

UPT Publikasi dan Pengelolaan Jurnal

Universitas Islam Kalimantan Muhammad Arsyad Al-Banjari Banjarmasin 
Widi Fajar Widyatmoko ${ }^{1}$, Ari Prasetyoaji ${ }^{2}$ Jurnal Mahasiswa BK An-Nur : Berbeda, Bermakna, Mulia

Volume 7 Nomor 3 Tahun 2021

Tersedia Online: https://ojs.uniska-bjm.ac.id/index.php/AN-NUR

p-ISSN. 2460-9722 | e-ISSN. 2622-8297

Studies $5(2)$,

https://doi.org/10.15642/jpai.2017.5.2.201.223

Safaat. 2011. Android Pemrograman Aplikasi Mobile Smartphone dan Tablet PC Berbasis Android. Informatika: Bandung

Setyosari, Punaji. 2013. Metode Penelitian Pendidikan \& Pengembangan. Prenamedia Grup: Jakarta

Ulum, Nafi'atul. 2020. Konsep Kecerdasan Majemuk Perspektif Howard Gardner dan Penerapannya dalam Pembelajaran di Madrasah Ibtidaiyah. Universitas Islam Negeri Sunan Ampel Surabaya.

Dipublikasikan Oleh :

UPT Publikasi dan Pengelolaan Jurnal

Universitas Islam Kalimantan Muhammad Arsyad Al-Banjari Banjarmasin 